\title{
Anemia, transfusion, and outcome: Both are bad...does it really matter which is worse?
}

\author{
Gaetano Paone, MD, MHSA
}

\author{
From the Division of Cardiac Surgery, Henry Ford Hospital, Detroit, Mich. \\ Disclosures: Author has nothing to disclose with regard to commercial support. \\ Received for publication March 13, 2018; accepted for publication March 19, 2018; available ahead of print April \\ $11,2018$. \\ Address for reprints: Gaetano Paone, MD, MHSA, Division of Cardiac Surgery, Henry Ford Hospital, 2799 West \\ Grand Blvd, Detroit, MI 48202 (E-mail: gpaone1@ comcast.net or gpaone1@hfhs.org). \\ J Thorac Cardiovasc Surg 2018;156:75-6 \\ $0022-5223 / \$ 36.00$ \\ Copyright (C) 2018 by The American Association for Thoracic Surgery \\ https://doi.org/10.1016/j.jtcvs.2018.03.051
}

An exhaustive, and some might even opine exhausting, literature has repeatedly demonstrated the association of red blood cell (RBC) transfusion with increased morbidity and mortality after coronary artery bypass grafting. ${ }^{1-3}$ An equally compelling volume of evidence similarly documents poor outcomes related to anemia that worsen further still when accompanied by transfusion. ${ }^{4-8}$ This is perhaps more simply stated as anemia is bad, transfusion is worse, and both together are worse than either one alone. With this large multicenter study of patients from the Virginia Cardiac Services Quality Collaborative undergoing isolated primary coronary artery bypass grafting, the authors add to the literature yet another attempt to unravel the conundrum of transfusion-related outcomes. 9

Using what I am certain was a sophisticated "risk adjusted hierarchical modeling of preoperative Hct as a continuous function" and "... adjustment for the confounding influence of baseline patient risk profile," the authors demonstrate that preoperative anemia was associated with an increase in the probability of RBC transfusion, the risk of postoperative renal failure, and mortality. Even stronger associations were noted between RBC transfusion and mortality, renal failure, and stroke.

These findings are neither surprising nor new and differ from other studies mainly in the statistical methodology that modeled hematocrit as a continuous rather than as a discrete variable or range of values. The conclusion that transfusion contributes more to poor patient outcomes than anemia alone does little to clarify our understanding of the clinical factors that drive this interaction between the risks of transfusion versus anemia and the subsequent association with outcome. Although the authors modeled preoperative hematocrit, they acknowledge that they did not consider the effects of intraoperative anemia. As with essentially all reports on transfusion-related outcomes, information regarding the level of hematocrit, in which patients, under which conditions, or for which specific clinical indications the transfusions were administered is lacking. Taken a step further, we are no better informed

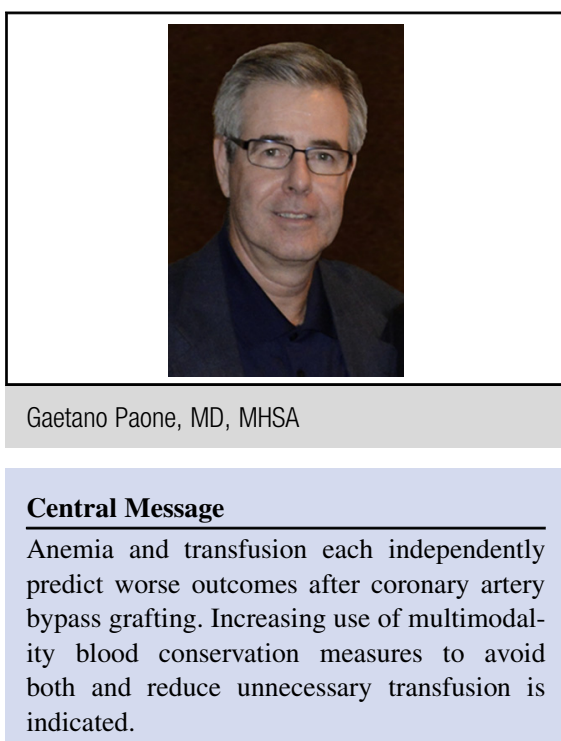

See Article page 66.

about the circumstances for which transfusion might be appropriate. Given 2 patients with the same hematocrit level, it would seem important to know why one received transfusion and the other did not before deciding that transfusion at a given level of anemia is harmful or responsible for a poor outcome.

Despite the inability to conclusively correlate transfusion with outcome as cause and effect, it remains appropriate to argue that avoiding transfusion can have both clinical and financial benefits. ${ }^{1,2}$ To this end, the real emphasis should be on avoiding the conditions that lead to transfusion. This study then is particularly worthwhile in that it leverages its results to make sensible recommendations regarding the benefits of comprehensive multimodality blood management programs to drive blood conservation. ${ }^{10,11}$ If worsening anemia predicts both need for transfusion and worsening outcome, then efforts to optimize preoperative hematocrit in concert with additional perioperative measures that further limit the degree of anemia should decrease the need for subsequent and what are often unnecessary transfusions. Whether due to the patient or due to the transfusion, patients do better without transfusions.

\section{References}

1. LaPar DJ, Crosby IK, Ailawadi G, Ad N, Choi E, Spiess BD, et al. Blood product conservation is associated with improved outcomes and reduced costs after cardiac surgery. J Thorac Cardiovasc Surg. 2013;145:796-803. 
2. Murphy GJ, Reeves BC, Rogers CA, Rizvi SI, Culliford L, Angelini GD. Increased mortality, postoperative morbidity, and cost after red blood cell transfusion in patients having cardiac surgery. Circulation. 2007;116:2544-52.

3. Paone G, Brewer R, Theurer PF, Bell GF, Cogan CM, Prager RL. Preoperative predicted risk does not fully explain the association between red blood cell transfusion and mortality in coronary artery bypass grafting. $J$ Thorac Cardiovasc Surg. 2012;143:178-85.

4. Williams ML, He X, Rankin JS, Slaughter MS, Gammie JS. Preoperative hematocrit is a powerful predictor of adverse outcomes in coronary artery bypass graft surgery: a report from the Society of Thoracic Surgeons adult cardiac surgery database. Ann Thorac Surg. 2013;96:1628-34.

5. Kilic A, Whitman GJ. Blood transfusions in cardiac surgery: indications, risks, and conservation strategies. Ann Thorac Surg. 2014;97:726-34.

6. Loor G, Koch CG, Sabik JF III, Li L, Blackstone EH. Implications and management of anemia in cardiac surgery: current state of knowledge. J Thorac Cardiovasc Surg. 2012;144:538-46.
7. Engoren M, Schwann TA, Habib RH, Neill SN, Vance JL, Likosky DS. The in dependent effects of anemia and transfusion on mortality after coronary artery bypass. Ann Thorac Surg. 2014;97:514-20.

8. Loor G, Rajeswaran J, Li L, Sabik JF, Blackstone EH, McCrae KR, et al. The least of 3 evils: exposure to red blood cell transfusion, anemia, or both? J Thorac Cardiovasc Surg. 2013;146:1480-7.e6.

9. Preoperative anemia versus blood transfusion: which is the culprit for worse outcomes in cardiac surgery? J Thorac Cardiovasc Surg. 2018; 156:66-74.

10. Brevig J, McDonald J, Zelinka ES, Gallagher T, Jin R, Grunkemeier GL. Blood transfusion reduction in cardiac surgery: multidisciplinary approach at a community hospital. Ann Thorac Surg. 2009;87:532-9.

11. Ferraris VA, Brown JR, Despotis GJ, Hammon JW, Reece TB, Saha SP, et al. 2011 update to the Society of Thoracic Surgeons and the Society of Cardiovascular Anesthesiologists blood conservation clinical practice guidelines. Ann Thorac Surg. 2011;91:944-82. 